\title{
The Business Strategy Study of 212 Mart
}

\author{
Irfan handoko"1, Arief Daryanto ${ }^{2}$, Sahara ${ }^{3}$ \\ "1,2School of Business, IPB University, Bogor, Indonesia \\ ${ }^{3}$ Departement of Economics, Economic and Management Faculty, IPB University, Bogor, Indonesia
}

\begin{abstract}
Article Info

Volume 8, Issue 3

Page Number: 363-370

Publication Issue :

May-June-2021

\section{Article History}

Accepted : 10 June 2021

Published: 15 June 2021

Retail sector is one of the economic sectors that drive the Indonesian economic growth. In 2020, this sector declined due to pandemic Covid 19. Minimarkets are one type of retail that can survive while many modern retailers had difficult times. It is an opportunity for businesses to compete in this sector. One of them is 212 Mart that focused on Indonesian muslim consumers is also affected by this pandemic. This study aims to formulate a 212 Mart business strategy using the latest information collected during the pandemic. This study discusses the environmental factors of 212 Mart using the IFE and EFE while the strategy is formulated uses a SWOT-QSPM analysis. The research results shows that there are management and distribution problems that occur in 212 Mart. The strategic priority generated in this study is to recruit new members or new investors as target consumers as well as business partners who are expected to improve the performance of 212 Mart.
\end{abstract}

Keywords : Minimarket, QSPM, Retail, Strategy, SWOT.

\section{INTRODUCTION}

The retail sector is one of the sectors that can drive Indonesia's economic growth. In 2020, this sector is one of the sectors that suffered losses due to the Covid 19 pandemic. As a business that sells various kinds of retail products, It is divided into traditional retail and modern retail. The first modern retailer in Indonesia has been around since 1962 under the name Sarinah, but the modern retail industry has only experienced rapid development in the early 2000s.

Contribution of modern retail in Indonesia in 2016 was $17.53 \%$, then decreased in 2017 and 2018 but returned to excitement in 2019, which shows the or higher than in 2016. The increase in the contribution of the modern market was mostly contributed by the minimarket business line, which contributed more than 10\% (USDA 2020).

2016 - 2017 was a difficult period for many modern retailers in Indonesia. Many big names have partially closed their outlets in Indonesia, including 7eleven and Matahari. However, these conditions do not have a major effect on the existence of minimarkets.

Minimarket is a type of modern retail that can survive this condition. While supermarkets and hypermarkets struggled to survive, the minimarkets showed good business development. In 2016, the number of minimarkets in Indonesia was 29,778 outlets. $\%$ Meanwhile, in 2017, minimarkets in Indonesia grew 
by nearly 3,000 outlets to 32,458 outlets. Even though the period of that year was a difficult period for the physical modern retail industry which faced the mushrooming digital market (e-commerce). The consistent growth trend was also continued by minimarkets in Indonesia in 2018 to 33,416 outlets and 2019 to 36,451 outlets (USDA 2020). The concept of a minimarket that is almost able to reach consumers is one of the factors in the development of the industry. Consumers prefer not only to shop practically, but also to shop in a place where the goods are complete, neat and hygienic.

Performance of the minimarket in 2017 has created an opportunity for businessmen to compete in the modern retail sector in minimarket format. One of the new players in the minimarket retail sector is Minimarket 212 Mart. As a newly established business, 212 Mart needs proper management steps to survive and compete with other minimarkets that have been around for a long time and have their large customers.

The establishment of 212 Mart in 2017 has become a new competitor among competition from the two big names of minimarkets today, Alfamart and Indomaret. The establishment of 212 Mart was based on the increasing sentiment of the public economy which was not supported by good business performance. The relatively low turnover of visitors caused the planned revenue target to not be achieved.

The decrease in the number of visits also resulted in a decreasing the turnover received by 212. It's allegedly due to the lack of good corporate governance at the corporate level and distribution in the field affected on the capital and budget side. 212 Mart has so far only been able to finance its core operational activities, make it had difficult to support operational activities such as promotions are very important.

On the other hand, the level of competition for minimarkets in Indonesia is getting higher.
Furthermore, in 2020, almost all economic activities in Indonesia will slow down due to the Covid-19 pandemic that has hit all aspects of Indonesian people's lives, which is a challenge for the 212 Mart minimarket to maintain its business.

As a newly established business, 212 Mart needs proper management steps to survive and compete with other minimarkets that have their large customers. It takes a business strategy that adapt to environmental conditions, the company can be controlled internally and the external environment is difficult to control.

This strategy is also required to achieve the goal of 212 Mart to build a trustworthy, professional, large and strong economy. This study aims to 1) analyze the strategies and levels of success that have been carried out by 212 Mart, 2) analyze the internal and external environmental conditions faced, and 3) formulate and recommend the right business strategy to 212 Mart.

The scope of this research focuses on the formulation of alternative business strategies for minimarket 212 Mart in terms of internal and external corporate environmental aspects.

\section{LITERATURE REVIEW}

Strategies often used to achieve goals. The application of strategy in business activities is an activity of analysis, decisions, and actions used to achieve a competitive advantage in organizations (Porter 2004); (Ketchen 2009). David (2009) mentions that strategy is a way to achieve short-term, medium-term, and long-term goals. In addition, companies also want to maintain their profits for a long time, so companies need to create competitive advantages that are unique, valuable, and difficult to imitate for a long time (Negara 2013).

According to Miller (1998); Soselisa (2017), there are three types of strategies in the business, the corporate 
level strategy formulated by top management which regulates operations with more than one line of business; Business-level strategy to compete directly with other players in the same industry with a range of similar products; and the functional level strategy as a group of action programs aimed to developing uniqueness to exceed or at least equal the capabilities of its competitors.

\section{METHODS OF RESEARCH}

This research was conducted in October 2020 February 2021 at Minimarket 212 Mart by taking several examples of outlets in the Greater Jakarta area (Jakarta, Bogor Depok, Tangerang, and Bekasi). The sampling technique was carried out deliberately (purposive sampling) using primary data and secondary data. This study discusses the internal and external environmental factors of the company obtained through observation, interviews, and filling out questionnaires by 10 sources from internal and external of 212 Mart.

The method used in this research is descriptive analysis to answer the first objective. The second objective is using the analysis of the company's environmental factors, the IFE matrix (Internal Factor Evaluation) and the EFE (External Matrix Evaluation) matrix, and the IE (Internal-External) matrix. Furthermore, the alternative strategy as a third research objective formulated with a SWOT matrix (Strengths, Weaknesses, Opportunities, Threats) and strategic prioritization using a QSP (Quantitative Strategic Planning) matrix.

\section{RESULT AND DISCUSSIONS}

Minimarket 212 Mart is one of the business lines operated by the 212 Sharia Cooperative (Koperasi syariah 212/KS 212). The establishment of 212 Mart was motivated by the 212 movements as one form of effort to build brotherhood and peace to achieve economic independence for the ummah with sharia principles as organizational guidelines. 212 Mart managed using Sharia principles based on the spirit of togetherness reflected in the 212 Mart minimarket tagline, namely congregation, amanah, and izzah. 212 Mart as one of the business lines of Koperasi Syariah 212 always conducts evaluations every year. The last Annual Member Meeting (RAT) was held by sharia cooperative 212 in December 2020. The first research objectives regarding the strategies that have made and the level of success that has carried out in the 20192020 such as:

a. Established 20 outlets of 212 Mart that KS 212 managed independently;

b. Increase the turnover of 212 Mart outlets by $20 \%$ from the previous turnover;

c. Increase profit sharing from 212 mart outlets by $2.5 \%$ by helping 212 mart outlets to prepare financial reports.

The strategy that has been declared has not met its target. The (a) strategy has only been realized by $25 \%$ or only 5 new outlets that have been established from the target of 20 outlets that must be established. Even KS 212 received reports that three registered outlets had closed their store on their way. It was due to the decrease in turnover experienced by 212 Mart. This underperformance is allegedly due to 212 Mart being late in taking anticipatory steps due to no longer working with expert partners who handle store operations. This condition confirms that there are serious problems with the management and distribution of 212 Mart.

The realization of the (b) and (c) strategy is related because it cannot be determined nominally considering that many 212 Mart outlets do not send their business reports to KS 212 as the parent cooperative. The mitigation step taken is the use of POS system technology in each of its operational activities, but encountered obstacles related to the readiness of each outlet to utilize this technology. 


\section{IFE and EFE analysis}

Internal Factor Evaluation (IFE) and External Factor Evaluation (EFE) matrices were used to answer the second research objective. The IFE matrix is formed based on the company's internal factors, both the strengths and weaknesses of the 212 Mart minimarket. The EFE matrix is formed based on the company's external factors, both in the form of opportunities and challenges owned by 212 Mart. The calculation of the matrix is based on the calculation of the weight and rating of each factor. The calculation results found that the average score of the internal evaluation results is 2.477, while the EFE calculation shows that the average score is 2.748. IFE scores below an average score of 2.50 indicate that 212 Mart has an internal weaknesses. An EFE score is above 2.50 illustrates that 212 Marts are good at responding to opportunities (David 2009); (Hindarwati \& Arifin 2015).

The biggest strength factor as the IFE analysis result is the halal product factor which guarantees 212 Mart (0.341). The halal label that functions to help consumers choose products without a doubt makes this factor considered very prospective considering the halal lifestyle that has become a trend nowadays (Evans and Evans, 2012). The product completeness factor is the biggest internal problem faced by 212 Mart (0.182).

Completeness of products and delays in supply are two things that should not happen to businesses in the modern retail sector, thus indicating that there is a management problem that is not well done by 212 Mart. If this condition continues, it is feared that it could affect the performance of 212 Mart. Ilmiyati \& Munawaroh (2016) said that the supply of goods can affect company performance which has an impact on decreasing consumer satisfaction and the desire to shop again. It shows that 212 Mart consumers are rational consumers who make decisions based on logic on factors such as price, service, quality, and location (Handi 2003); (Fahmi 2016). The results of the internal environmental evaluation are presented in table 1.

TABLE 1. IFE 212 MART ANALYSIS ANALYSIS

\begin{tabular}{|c|c|c|c|}
\hline Internal factors & $\begin{array}{l}\text { Weight } \\
\text { (a) }\end{array}$ & $\begin{array}{l}\text { Rating } \\
\text { (b) }\end{array}$ & $\begin{array}{l}\text { Score } \\
\text { (axb) }\end{array}$ \\
\hline \multicolumn{4}{|l|}{ Strengths } \\
\hline Vision and mission & 0.079 & 2.70 & 0.213 \\
\hline $\begin{array}{l}\text { Guarantee of the } \\
\text { halalness product }\end{array}$ & 0.103 & 3.30 & 0.341 \\
\hline Location affordability & 0.085 & 2.50 & 0.212 \\
\hline Private label & 0.082 & 2.70 & 0.222 \\
\hline $\begin{array}{l}\text { Community based } \\
\text { business }\end{array}$ & 0.097 & 2.80 & 0.272 \\
\hline Suppliers partners & 0.070 & 2.40 & 0.168 \\
\hline \multicolumn{4}{|l|}{ Weaknesses } \\
\hline Product completeness & 0.073 & 2.50 & 0.182 \\
\hline Delay in supply & 0.070 & 2.40 & 0.167 \\
\hline High rent fees & 0.070 & 2.10 & 0.147 \\
\hline Promotion rarely & 0.067 & 210 & 0.140 \\
\hline $\begin{array}{l}\text { Lack of relationship } \\
\text { with non-cooperative } \\
\text { customers }\end{array}$ & 0.061 & 1.80 & 0.109 \\
\hline $\begin{array}{l}\text { The use of IT facilities } \\
\text { is not optimal }\end{array}$ & 0.076 & 2.20 & 0.167 \\
\hline $\begin{array}{l}\text { Customer segmentation } \\
\text { has not been well } \\
\text { managed }\end{array}$ & 0.067 & 2.00 & 0.134 \\
\hline Total & 1.000 & & 2.477 \\
\hline
\end{tabular}

The greatest opportunity in the EFE analysis is the variation factor of the MSME product offered (0.401) so that it needs to be utilized as well as possible. It can 
be an alternative for additional income and create its image for 212 Mart as a minimarket that supports MSMEs. The declining factor of the modern retail trend is the biggest threat that needs to be noticed for 212 Mart (0.228). This condition is a result of the spread of the COVID 19 pandemic (S\&P Global 2020) which has caused the shopping habits of many people to switch from physical visits to online shopping. Grab data (2020) shows that there was an increase in GrabExpress orders in March 2020 by $21.5 \%$ and housing became the most delivery point by $41.5 \%$ compared to before the pandemic. It shows that indicates that people tend to have new habits by shopping online. The results of the external environment evaluation are presented in table 2.

The next step is to find out the position of the company using an internal-external matrix (IE). This matrix collaborates the results of the evaluation of internal and external factors that have been carried out. Based on the results of the calculation of the IFE matrix, the weight score is 2.477 and the EFE matrix is obtained a score of 2.748. This score indicates that 212 Mart needs to take advantage of existing opportunities optimally to minimize management deficiencies that are currently a company's problem. IE Matrix are presented in figure 1.

\section{FIGURE 1. IE MATRIX.}

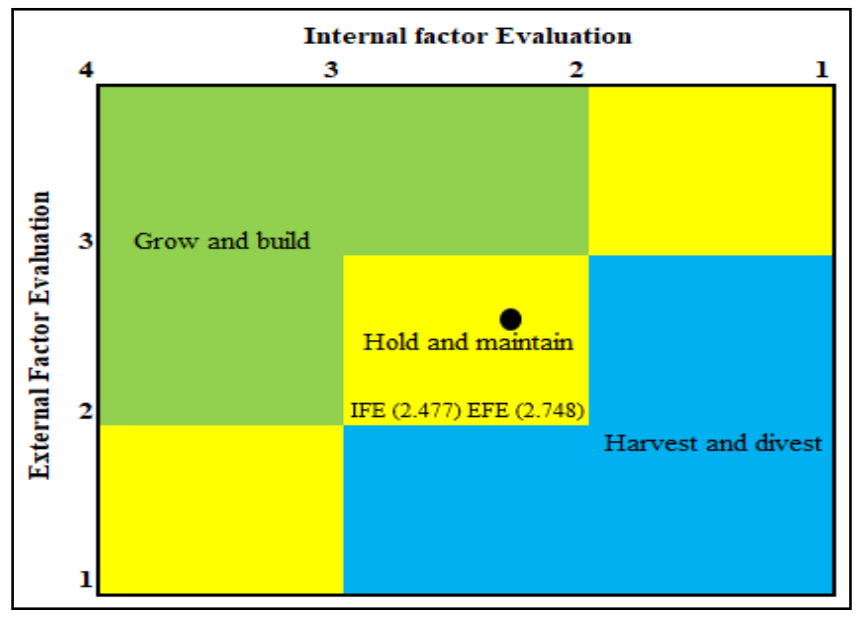

The business strategy recommendations for 212 Mart formulated by a SWOT matrix analysis. The SWOT matrix formulates alternative strategies by taking the various conditions experienced by 212 Mart. Strategy formulation is focused on utilizing the conditions owned by the company as an effort usually made by business actors to make a plan (Valentin 2001).

Each SWOT matrix strategy alternative formulation is: 1) SO (Strengths-Opportunities) strategy consisting of a) recruiting new members or investors; b) private label development, 2) ST (Strengths-Threats) strategy consisting of a) promotion and education around 212 Mart through social media and activities b) collaboration with third parties for delivery services;

TABLE 2. EFE 212 MART ANALYSIS RESULT.

$\begin{array}{llll}\text { External factors } & \begin{array}{l}\text { Weight } \\ \text { (a) }\end{array} & \begin{array}{l}\text { Rating } \\ \text { (b) }\end{array} & \begin{array}{l}\text { Score } \\ (\mathrm{axb})\end{array}\end{array}$

Opportunities

\begin{tabular}{llll}
\hline $\begin{array}{l}\text { Large } \\
\text { population }\end{array}$ & 0.108 & 3.20 & 0.345
\end{tabular}

Potential program

activities with the $0.104 \quad 2.90 \quad 0.303$

community

IT development $\quad 0.108 \quad 3.30 \quad 0.356$

Presiential

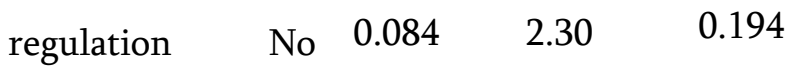

112/2017

\begin{tabular}{llll}
$\begin{array}{l}\text { Variety of MSME } \\
\text { products }\end{array}$ & 0.114 & 3.50 & 0.401 \\
\hline
\end{tabular}

Threats

$\begin{array}{llll}\text { Lots of existing } & 0.081 & 2.50 & 0.202\end{array}$

minimarket

$\begin{array}{llll}\text { Covid } 19 & 0.077 & 2.30 & 0.178\end{array}$

Lots of $\quad \mathrm{e}^{-} \quad 0.081 \quad 2.10 \quad 0.170$

commerce

The decreasing $0.088 \quad 2.60 \quad 0.228$ trend of the 
modern retail

business

Allows

competitors to use

the same

$0.074 \quad 2.20 \quad 0.163$

distributor services

Consumer loyalty

of non-member

$\begin{array}{lll}0.081 & 2.60 \quad 0.210\end{array}$

cooperative

Total

1.000

2.748

3) WO (Weaknesses-Opportunities) strategy, namely improving the IT system; and 4) the WT (Weaknesses-Threats) strategy consisting of a) evaluation of cooperation with business partners $b$ ) building a systematic regional inventory warehouse. The results of the SWOT matrix analysis are presented in figure 2 .

FIGURE 2. 212 MART SWOT MATRIX.

\begin{tabular}{|c|c|}
\hline \multicolumn{2}{|c|}{ SWOT Matrix } \\
\hline $\begin{array}{l}\text { WO Strategy } \\
\text { 1. Upgrading IT system (W1, } \\
\text { W2, W3, W4, O1, O2, O3, } \\
\text { O5) }\end{array}$ & $\begin{array}{l}\text { SO Strategy } \\
\text { 1. Recruitment of new } \\
\text { members or investors as } \\
\text { target customers as well as } \\
\text { business partners (S1, S3, } \\
\text { S4, S5, O1, O2, O4, O5). } \\
\text { 2. Private label development } \\
\text { (S1, S2, S4, S5, O1, O2, O3, } \\
\text { O5) }\end{array}$ \\
\hline $\begin{array}{l}\text { WT Strategy } \\
\text { 1. Cooperation agreements } \\
\text { evaluation with business } \\
\text { partners (W1, W3, W4, T1, } \\
\text { T4) } \\
\text { 2. Build a systematized } \\
\text { regional warehouse }(\mathrm{W} 1 \text {, } \\
\text { W2, W6, T1, T3, T4, T5) }\end{array}$ & $\begin{array}{l}\text { ST Strategy } \\
\text { 1. Promotion and education to } \\
\text { the community around } 212 \\
\text { Mart through social activites } \\
\text { and social media (S1, S2, S4, } \\
\text { S5, T1, T2, T3, T5) } \\
\text { 2. Cooperation with third } \\
\text { parties for delivery services } \\
\text { (W3, W4, T1, T2, T3, T5) }\end{array}$ \\
\hline
\end{tabular}

The next step in determining strategic priorities to accommodate the objectives of the third study was carried out using a QSPM matrix analysis. The quantitative strategic planning matrix (QSPM) is a stage of decision making. This matrix determines the best alternative strategy using input in the form of environmental analysis results and several alternatives strategies that have been made to optimize strengths and challenges, improve weaknesses, and avoid threats (Alianto 2005) (David 2009) (Sanghaei 2012) (Wahyuningsih 2016) (Sumiarsih 2018).

The QSPM result show that the recruitment of new members or investors is a priority strategy for implementation with a score of (5.452). The alternative strategy for recruiting new members or investors is the main priority produced by the QSPM matrix to minimize the capital problems currently faced by 212 Mart to increase its sources of funds. The success of this strategy is expected to make it easier for 212 Mart to implement other alternative strategies. The next alternative strategy according to the priority level is presented in table 3 .

The success of the hold and maintain strategy is determined by the successful implementation at the business and functional levels. The recommended strategy based on IE analysis is translated into market penetration and product development. Both strategies are elaborated into several alternative strategies at the functional level. Market penetration is carried out by taking advantage of the uniqueness of 212 Mart, namely recruiting new members in addition to functioning as potential customers as well as functioning as investors to increase the capital of 212 Mart. The success of the recruitment of KS 212 members is determined by the executor in the community section to promote and disseminate information related to 212 Mart which can be done through social media and activities.

TABLE 3. QSPM RESULT OF 212 MART

\begin{tabular}{llll} 
No & Priority Strategy & STAS \\
\hline $\begin{array}{l}\text { Recruitment of new members or } \\
\text { investors }\end{array}$ & 5.452
\end{tabular}

2. Upgrading IT system 
3. Systematized regional warehouse

4. Private label development

5. Promotion and education through social media and social activities

6. Cooperation agreements evaluation 4.970 with business partners

7. Cooperation with third parties for 4.955 delivery services

In addition, the business and operational departments can collaborate with expert partners to increase the utilization of IT systems. Such utilization also needs to be refined by drafting clear standard operating procedures (SOP) along with regular training for employees as users. This is necessary to mitigate management constraints that have occurred. Build an inventory warehouse/ mini DC either simultaneously or sequentially based on priorities is expected to minimize the weaknesses of 212 Mart related to supply. The private label owned by 212 Mart is currently in the form of bottled drinking water (AMDK), which is considered to be still developing. Several basic food products can be developed and become alternatives as a product development effort to create a company's uniqueness so that it is difficult for competitors to imitate. Management can work together with production partners in a maklon (devolution of production to other parties) so that 212 Mart can focus on its main business as a retailer.

\section{CONCLUSION}

212 Mart as a new player has the confidence to compete in the competition for minimarket retail in Indonesia. Several strategies have been implemented that have not been able to provide satisfactory results. Periodic evaluations need to improve the performance of 212 Mart.

The results of the IFE and EFE analysis provide information that the distribution and managerial of
212 Mart is still an obstacle that needs to be fixed immediately. This research offers a hold and maintains strategy at 212 Mart through market penetration and product development. It can be done by looking for uniqueness both product and operationally to offer different things to consumers

This study formulates strategic priorities based on the attractiveness value of the company's environmental factors. So that for the implementation of the strategy, it is necessary to prepare an action plan with realistic time details. Standard operating procedures (SOP) also need to be formulated and socialized in the internal 212 Mart so that it is expected to become a guide and help uniform strategy for all elements including internal 212 Mart.

Strategy formulation and further research are suggested to evaluate the implementation of the strategies recommended in this study and pay attention to the factors that affect the company's performance from the consumer side in order to enrich the research repertoire regarding strategy development in the minimarket retail industry.

\section{REFERENCES}

[1]. Alianto, H. 2005. Penerapan manajemen strategis pada pt optic XYZ. Jurnal BEe-SISFO. 2(1): $36-56$.

[2]. David, F. R. (2009). Manajemen strategis: konsep (terjemahan). Jakarta (ID): Salemba Empat.

[3]. Evans, A. D., Evans, S. (2012). Halal market dynamic: an analysis. London (UK): Imarat Consultants.

[4]. Fahmi, I. (2016). Perilaku konsumen (teori dan aplikasi). Bandung (ID): CV Alfabeta.

[5]. Grab. (2020). Ini 5 perubahan kebiasaan masyarakat Indonesia selama pandemi COVID 19. Retrieved from: www.grab.com/id/blog/ini5-perubahan-kebiasaan-masyarakat-Indonesiaselama-pandemi-COVID-19. 
[6]. Hindarwati, E. N., Arifin, S. B. (2015). Penerapan strategi bisnis pada perusahaan kontraktor tiang pancang di Indonesia. Jurnal Manajemen Indonesia. 15(3): 243 - 252.

[7]. Ilmiyati, A., Munawaroh, M. (2016). Pengaruh manajemen rantai pasokan terhadap keunggulan kompetitif dan kinerja perusahaan (studi pada usaha kecil dan menengah di kabupaten Bantul). Jurnal Manajemen Bisnis. 7(2): $226-251$.

[8]. Ketchen Jr, D. 2009. Strategy 2008-2009. New York (US): McGraw Hill.

[9]. Miller, A. (1998). Strategic management. New York (US): McGraw Hill.

[10]. Negara, A. A. (2013). Strategi pengembangan usaha bisnis franchise dalam bidang fast food (studi kasus sebuah bisnis franchise fast food di kota Bogor). (Master theses, IPB University, Bogor, Indonesia).

[11]. S\&P Global. (2020). Chinese coronavirus fear spreads over luxury, retail sectors. Retrieved from: http://www.spglobal.com/en/researchinsight/articleschinese-coronavirus-fearspreads-over-luxury.

[12]. Sanghaei, M. (2012). Strategic planning for a lubricant manufacturing company using SWOT analysis, QSPM model (one of the top companies of Iranian oil, gas, and petrochemical product exporters' association). Australian Journal of Business and Management research. 1(10): $18-24$.

[13]. Soselisa, J. A. (2017). Strategi pengembangan usaha supermarket XYZ dengan menggunakan pendekatan model bisnis kanvas. (master theses, IPB University, Bogor, Indonesia).

[14]. Sumiarsih, N. M., Legono, D., Kodoatie, R. J. (2018). Strategic sustainable management for water transmission system: a SWOT-QSPM analysis. Journal of the Civil Engineering Forum. 4(1). $29-40$.

[15]. USDA Foreign Agricultural Service. (2020. Indonesia: retail foods update. Retrieved from: https://www.fas.usda.gov/data/indonesia-retailfoods-2.

[16]. Valentin, E. K. (2001). SWOT analysis from a resourced-based view. Journal of Marketing Theory and Practice. 9(2): 54 - 69.

[17]. Wahyuningsih, T. (2016). The development strategy of main commodities of rice in buru district, Maluku. World journal of Agricultural Research. 4(1): 230 - 238.

\section{Cite this article as :}

Irfan Handoko, Arief Daryanto, Sahara, "The Business Strategy Study of 212 Mart", International Journal of Scientific Research in Science, Engineering and Technology (IJSRSET), Online ISSN : 2394-4099, Print ISSN : 2395-1990, Volume 8 Issue 3, pp. 363-370, May-June 2021. Available at doi : https://doi.org/10.32628/IJSRSET218361 Journal URL : https://ijsrset.com/IJSRSET218361 